\title{
Rafal Boguszewski*
}

iD https://orcid.org/0000-0002-1831-4265

\section{Tomasz Herudziński**}

iD https://orcid.org/0000-0002-4102-2957

\section{Artur Obidziński***}

iD https://orcid.org/0000-0002-8750-7845

\section{WIEDZA O WLASNEJ MIEJSCOWOŚCI I ZAANGAŻOWANIE W SPRAWY LOKALNE ORAZ ICH DETERMINANTY NA PRZYKLADZIE SPOLECZNOŚCI WIEJSKIEJ}

\begin{abstract}
Abstrakt. Zmiany zachodzące obecnie na obszarach wiejskich w Polsce wpisują się w koncepcję ,,inteligentnych wsi” (smart villages), która akcentuje znaczenie wiedzy i działań innowacyjnych dla funkcjonowania współczesnych wiejskich społeczności lokalnych i rozwoju obszarów wiejskich. Artykuł odnosząc się do zagadnienia społeczności lokalnej, przybliża obraz mieszkańców wsi Czarny Las, zwracając uwagę na specyfikę tej społeczności. W wymiarze empirycznym zasadniczym celem autorów jest weryfikacja tezy o występowaniu zależności pomiędzy wiedzą o własnej miejscowości a zaangażowaniem w lokalne sprawy na przykładzie konkretnej społeczności wiejskiej, jak również ustalenie czynników wpływających na oba wymiary. W tym celu zbudowano i wykorzystano wskaźniki dotyczące z osobna wiedzy i zaangażowania mieszkańców wsi Czarny Las w gminie Grodzisk Mazowiecki. Jako predyktory zarówno wiedzy o własnej wsi, jak i zaangażowania w jej bieżące sprawy przyjęto wiek, płeć, wykształcenie, czas zamieszkiwania w badanej miejscowości oraz formalny stan zameldowania. W celu określenia istotności statystycznej predyktorów wiedzy mieszkańców o miejscowości i ich zaangażowania na jej rzecz posłużono się analizą regresji wielokrotnej.
\end{abstract}

Słowa kluczowe: wiedza, działanie, obszary wiejskie, społeczność lokalna, inteligentna wieś.

* Szkoła Główna Gospodarstwa Wiejskiego w Warszawie, e-mail: rafal_boguszewski@, sggw.edu.pl

** Szkoła Główna Gospodarstwa Wiejskiego w Warszawie, e-mail: tomasz_herudzinski@ sggw.edu.pl

*** Szkoła Główna Gospodarstwa Wiejskiego w Warszawie, e-mail: artur_obidzinski@ sggw.edu.pl 


\section{Wstęp}

\subsection{Wybrane trendy funkcjonowania społeczności obszarów wiejskich}

Opis konkretnej społeczności lokalnej pod kątem jej wiedzy i zaangażowania w działania na własną rzecz, co będzie miało miejsce w dalszej części artykułu, warto rozpocząć od nakreślenia podstawowych tendencji rozwojowych dotyczących społeczności obszarów wiejskich w ogóle. Ze względu na rozległość zagadnienia przemian obszarów wiejskich uwagę skoncentrowano tu na kwestiach istotnych z perspektywy przedstawionych w tytule wiedzy i aktywności mieszkańców. Jawią się one jako szczególnie ważne w perspektywie koncepcji ,inteligentnych wsi" (smart villages), której zasadniczym założeniem jest rozwój obszarów wiejskich w oparciu o wiedzę. W takim podejściu uważa się, że mieszkańcy wsi podlegają analogicznym zmianom jak mieszkańcy miast, a obszary wiejskie traktuje się jako element składowy społeczeństwa określanego jako społeczeństwo wiedzy, informacyjne czy postindustrialne (Bielska i in. 2021). Istotnym elementem koncepcji inteligentnej wsi jest takie funkcjonowanie społeczności lokalnych, w którym dominują działania o charakterze innowacyjnym i które sprzyja wszechstronnemu wykorzystaniu lokalnych zasobów. W tej perspektywie jednostki posługują się strategiami podporządkowanymi kształceniu się przez całe życie (life-long learning). A rozwój wsi w duchu smart village, w szczególności działania w zakresie wdrażania konkretnych polityk publicznych, zakłada konieczność uwzględniania zmian socjoekonomicznych zachodzących na obszarach wiejskich, zwłaszcza istniejących negatywnych tendencji, takich jak wyludnianie, malejąca liczba rolników, słabo rozwinięty sektor usług i szerzej ujmując - pozarolniczy rynek pracy oraz trudności komunikacyjne - zarówno w wymiarze konwencjonalnym, jak i w zakresie cyfryzacji.

Jako że dostrzeżono (również na poziomie instytucjonalnym), że samo wspieranie rolnictwa np. za pomocą programów Wspólnej Polityki Rolnej UE jest niewystarczające, zwrócono uwagę na konieczność wspierania pozazawodowej sfery życia mieszkańców obszarów wiejskich. W koncepcji smart villages klucza do rozwiązań istniejących problemów społeczności wiejskich poszukuje się przede wszystkim w zmianach relacji międzyludzkich, tworzeniu nowych i wykorzystaniu starych sieci społecznych, często przy użyciu nowoczesnych technologii, ale przy jednoczesnym wyraźnym określeniu ich wymiaru technologicznego tylko jako narzędzia wykorzystywanego przez jednostki i społeczności, a nie jako celu samego w sobie. Przykładem może być seria cyfrowych inicjatyw obywatelskich, które pozwalają podnieść jakość usług świadczonych na obszarach wiejskich Unii Europejskiej, zaprezentowana w broszurze Innowacje cyfrowe i spoleczne w kontekście ustug na obszarach wiejskich (Skakelja 2018).

Innym zasadniczym problemem, który dotyka dziś wieś, jest depopulacja. Pozornie korzystny wskaźnik przyrostu liczby mieszkańców wsi może prowadzić 
do uproszczonego wniosku, że jest dobrze, ponieważ w ostatnich latach przybywa nam mieszkańców wsi. Kiedy jednak przyjrzymy się bliżej i uwzględnimy rozkład przestrzenny migracji, to owo pierwsze pozytywne wrażenie zmieni się i dostrzeżemy negatywne strony tego pozornie korzystnego zjawiska. Przybywa mieszkańców wsi, ale w okolicach dużych miast i jest to efekt słabo kontrolowanej urbanizacji terenów podmiejskich. W wielu miejscach ten często chaotyczny proces powoduje napięcia społeczne i wywołuje konflikty (Hałasiewicz 2020: $179,178)$.

I jak zauważa Jerzy Wilkin, koncepcja smart villages, mimo że harmonijnie związana z istniejącymi i wdrażanymi już programami UE, nie narzuca

[...] jednego uniwersalnego rozwiązania, lecz stanowi podejście terytorialnie dopasowane, oparte na potrzebach i potencjałach konkretnego, danego miejsca i lokalnej społeczności, realizowane i wspierane przez nowe lub istniejące strategie terytorialne. Jest to bardzo ważne ze względu na bardzo duże zróżnicowanie obszarów wiejskich w krajach UE (Wilkin 2020: 29).

\subsection{Specyfika lokalnej społeczności mieszkańców Czarnego Lasu}

Przedmiotem badania była wiedza mieszkańców wsi Czarny Las na temat ich miejscowości oraz ich zaangażowanie w życie wsi, a w szczególności stosunek do planowanej tam budowy świetlicy. Wieś Czarny Las jest położona na południowo-zachodnim obrzeżu gminy Grodzisk Mazowiecki w województwie mazowieckim. Założona została w $1850 \mathrm{r}$. jako osada czynszowa o powierzchni 206 mórg, złożona z 14 zagród. Według spisu ludności z 1921 r. Czarny Las zamieszkiwało 104 mieszkańców w 16 gospodarstwach, a w 1970 r. 154 osoby w 33 gospodarstwach. Rolniczy charakter wsi zaniknął po 1990 r. i od tego czasu rozwija się zabudowa indywidualna (Murzyn 2020). W wyniku niemal całkowitego wyludnienia wsi w latach 80 . XX w. i nowego osadnictwa po 2000 r. nastąpiła prawie stuprocentowa wymiana mieszkańców. Nowi mieszkańcy pochodzą z wielu regionów Polski, a nawet świata. W momencie badań wieś zamieszkiwało ponad 600 osób w blisko 300 domach. Od około 2000 r., wraz z napływem nowych mieszkańców, pojawiają się wspólne działania, jak np. wiosenne sprzątanie, protest przeciwko budowie linii wysokiego napięcia $400 \mathrm{kV}$, budowa placu zabaw, a następnie świetlicy, festyny sołeckie, szkolenia miejscowe i wyjazdowe oraz inne aktywności. Od momentu wprowadzenia funduszy sołeckich w $2006 \mathrm{r}$. sołectwo wykorzystuje je do finansowania wymienionych wyżej działań. Mieszkańcy corocznie decydują o ich przeznaczeniu na zebraniach wiejskich. Spotykają się też na wspomnianych akcjach. O planowanych działaniach informują ogłoszenia wywieszane na tablicach przyulicznych, strona internetowa sołectwa i newsletter. W badanej wsi działa koło gospodyń wiejskich, przy czym ma ono charakter stowarzyszenia towarzyskiego, na którego spotkaniach jego członkinie dzielą się różnego rodzaju umiejętnościami. Dzięki akcjom inicjowanym przez radę sołecką następuje stopniowa integracja mieszkańców. Społeczność analizowanej wsi jest 
też dobrze skomunikowana cyfrowo: ponad 120 mieszkańców odbiera regularne ogłoszenia mailowe od pani sołtys, ponad 300 mieszkańców korzysta ze strony na Facebooku, na której zamieszczane są różne informacje, w tym ogłoszenia dotyczące wzajemnej pomocy oraz usług. Wiele nadziei na dalszą integrację niesie otwarcie w 2020 r. świetlicy wiejskiej (Błońska i in. 2020).

\section{Metodyka badań}

\subsection{Założenia ogólne}

Prezentowane dane użyte do analizy empirycznej uzyskano w wyniku realizacji szerszego projektu badawczego wykonanego dla władz gminy Grodzisk Mazowiecki (Boguszewski, Herudziński 2019). Badanie zrealizowano 6 kwietnia 2019 r. we wsi Czarny Las. Badaną populację stanowili reprezentanci poszczególnych gospodarstw domowych. Każdorazowo był to jeden dorosły przedstawiciel gospodarstwa odwiedzonego przez ankietera. W założeniu badanie miało charakter wyczerpujący. Braki danych spowodowane były niedostępnością niektórych mieszkańców lub odmowami udzielenia wywiadu. Łącznie w badaniu wzięło udział 120 osób będących przedstawicielami 120 gospodarstw domowych (Tabela 1.). Analizowane tu dane zostały już częściowo wykorzystane w artykule odnoszącym się do zjawiska tzw. nowych mieszkańców wsi (Herudziński 2020).

Tabela 1. Struktura próby

\begin{tabular}{|l|l|c|c|}
\hline $\begin{array}{c}\text { Zmienne społeczno- } \\
\text {-demograficzne }\end{array}$ & \multicolumn{1}{|c|}{ Pleć } & N & \% \\
\hline \multicolumn{1}{|c|}{1} & \multicolumn{1}{|c|}{2} & 3 & 4 \\
\hline \multirow{4}{*}{ Płeć } & kobieta & 68 & 57,6 \\
\cline { 2 - 4 } & mężczyzna & 50 & 42,4 \\
\hline \multirow{5}{*}{ Wiek } & $18-35$ & 23 & 19,7 \\
\cline { 2 - 4 } & $36-45$ & 26 & 22,2 \\
\cline { 2 - 4 } & $45-65$ & 45 & 38,5 \\
\cline { 2 - 4 } & powyżej 65 lat & 23 & 19,7 \\
\hline \multirow{5}{*}{ Wykształcenie } & $\begin{array}{l}\text { podstawowe, } \\
\text { gimnazjalne lub } \\
\text { zawodowe }\end{array}$ & 8 & 6,8 \\
\cline { 2 - 4 } & $\begin{array}{l}\text { średnie lub } \\
\text { pomaturalne }\end{array}$ & 27 & 22,9 \\
\cline { 2 - 4 } & wyższe & 83 & 70,3 \\
\hline
\end{tabular}




\begin{tabular}{|l|l|c|c|}
\hline \multicolumn{1}{|c|}{1} & \multicolumn{1}{|c|}{2} & 3 & 4 \\
\hline \multirow{4}{*}{$\begin{array}{l}\text { Czas zamieszkiwania } \\
\text { w Czarnym Lesie }\end{array}$} & mniej niż 5 lat & 35 & 29,7 \\
\cline { 2 - 4 } & od 5 do 10 lat & 40 & 33,9 \\
\cline { 2 - 4 } & od 11 do 20 lat & 26 & 22,0 \\
\cline { 2 - 4 } & powyżej 20 lat & 17 & 14,4 \\
\hline \multirow{2}{*}{$\begin{array}{l}\text { Zameldowanie w } \\
\text { Czarnym Lesie }\end{array}$} & tak & 80 & 32,2 \\
\cline { 2 - 4 } & nie & 38 & 67,8 \\
\hline
\end{tabular}

Źródło: Opracowanie własne na podstawie wyników zrealizowanego badania.

Badanie zostało zrealizowane metodą sondażu z wykorzystaniem techniki wywiadu osobistego typu face to face przy użyciu kwestionariusza papierowego PAPI (Pen and Paper Interview). Kwestionariusz ankiety zastosowany w badaniu zawierał szereg pytań dotyczących wiedzy mieszkańców na temat zamieszkiwanej przez nich miejscowości i zaangażowania respondentów w życie lokalnej społeczności. Do oceny wiedzy mieszkańców na temat miejscowości, w której mieszkają, oraz ich zaangażowania w życie wsi zostały stworzone dwa osobne sumaryczne wskaźniki oparte na szeregu różnych pytań - dalej określane jako wskaźnik wiedzy i wskaźnik zaangażowania. Odpowiedzi na pytania wchodzące w zakres wskaźników zostały wystandaryzowane i mierzone w stustopniowej skali ciągłej. Przeciętne wskaźniki zbiorcze wiedzy i zaangażowania obliczono jako średnie arytmetyczne wartości punktów uzyskanych za odpowiedzi na wszystkie pytania wchodzące w zakres danego wskaźnika. Wartości wskaźników porównano dla następujących elementów charakterystyki respondentów: wiek, płeć, wykształcenie, czas zamieszkiwania w miejscowości, fakt zameldowania lub nie. Sześć początkowych miar wykształcenia zagregowano w trzy zbliżone liczebnie grupy, łącząc trzy najniższe i najmniej liczne kategorie wykształcenia w jedną. Ponadto zbadano korelację między obydwoma zbiorczymi wskaźnikami, tj. wiedzy i zaangażowania, oraz wykonano dla każdego wskaźnika z osobna wielozmiennową analizę regresji liniowej, w której zmienne wyjaśniające stanowiły podane wyżej cechy respondentów.

\subsection{Wskaźnik wiedzy}

Wskaźnik wiedzy obliczono na podstawie wyników odpowiedzi na następujące pytania:

1) Czy zna Pan/Pani sołtysa Czarnego Lasu? (Tak, osobiście $=100$ pkt; Tak, ale jedynie z widzenia/ze styszenia $=50 \mathrm{pkt}$; Nie znam, nie wiem, kto jest soltysem Czarnego Lasu $=0 \mathrm{pkt}$ ).

2) Ilu zna Pan/Pani członków rady sołeckiej Czarnego Lasu? - osobiście lub z widzenia/słyszenia (Znajomość 5 osób $=100 \mathrm{pkt} ; 4$ osób $=80$ pkt; 3 osób $=60 \mathrm{pkt}$; 2 osób $=40 \mathrm{pkt} ; 1$ osoby $=20 \mathrm{pkt} ; 0$ osób $=0 \mathrm{pkt})$. 
3) Czy wie Pan/Pani, kto jest radnym miasta Grodzisk Mazowiecki z Pana/Pani rejonu? (Znajomość 2 nazwisk $=100$ pkt; znajomość 1 nazwiska $=50$ pkt; nieznajomość nazwisk $=0$ pkt).

4) Czy wie Pan/Pani, jak nazywa się burmistrz miasta Grodzisk Mazowiecki? (Znajomość nazwiska burmistrza $=100$ pkt; nieznajomość $=0$ pkt).

5) Czy wie Pan/Pani, jak nazywają się wiceburmistrzowie miasta Grodzisk Mazowiecki? (Znajomość 2 nazwisk $=100$ pkt; znajomość 1 nazwiska $=50$ pkt; nieznajomość nazwisk $=0 \mathrm{pkt})$.

6) Czy wie Pan/Pani, gdzie w Czarnym Lesie znajduje się: sklep, przedszkole, plac zabaw, miejsce budowy świetlicy, dom sołtysa, stacja uzdatniania wody (Znajomość 5 lub 6 miejsc $=100$ pkt; znajomość 4 miejsc $=80$ pkt; znajomość 3 miejsc $=60 \mathrm{pkt} ;$ znajomość 2 miejsc $=40 \mathrm{pkt}$; znajomość 1 miejsca $=20 \mathrm{pkt}$; nieznajomość żadnego miejsca $=0$ pkt).

7) Czy wie Pan/Pani o planowanej budowie świetlicy w Czarnym Lesie? (Tak=100 pkt; Nie $=0 \mathrm{pkt})$.

8) Czy zna Pan/Pani planowaną lokalizację przyszłej świetlicy? (Tak = 100 pkt; Nie $=0 \mathrm{pkt})$.

\subsection{Wskaźnik zaangażowania}

Wskaźnik zaangażowania zawiera odpowiedzi na następujące pytania:

1) Ilu mniej więcej mieszkańców Czarnego Lasu (z wyjątkiem domowników) zna Pan/Pani z imienia i nazwiska? (Nie znam innych mieszkańców poza domownikami $=0$ pkt; mniej niż 5 osób $=20$ pkt; $5-10$ osób $=40$ pkt; $11-20$ osób $=60 \mathrm{pkt} ; 21-40$ osób $=80 \mathrm{pkt}$; powyżej 40 osób $=100 \mathrm{pkt}$ ).

2) Czy zdarza się Panu/Pani odwiedzać innych mieszkańców Czarnego Lasu $\mathrm{w}$ ich domach? (Nie $=0$ pkt; Bywam w 1 domu $=10$ pkt; Bywam $w 2$ domach $=20$ pkt; 3 domach $=30$ pkt... itd.; Bywam $w 10$ i więcej domach $=100$ pkt).

3) Czy zdarzyło się Panu/Pani korzystać z pomocy sąsiedzkiej lub jej udzielać? $($ Nie $=0 \mathrm{pkt} ;$ Tak - udzielatem lub korzystatem $=50 \mathrm{pkt}$; Tak - zarówno udzielatem, jak $i$ korzystatem $=100$ pkt).

4) Czy jest Pan/Pani członkiem jakiejś formalnej lub nieformalnej grupy mieszkańców? (Nie $=0$ pkt; Tak $=100$ pkt).

5) W których z wymienionych form aktywności lokalnej zdarzyło się Panu/Pani uczestniczyć: zebrania sołeckie/festyny wiejskie/wiosenne sprzątanie wsi/ szkolenia na miejscu/szkolenia wyjazdowe/inne? (Udziat w 5 lub 6 formach aktywności $=100 \mathrm{pkt} ; w 4$ formach $=80 \mathrm{pkt} ; w 3$ formach $=60 \mathrm{pkt} ; w 2$ formach $=40 \mathrm{pkt} ; w 1$ formie $=20 \mathrm{pkt}$; brak uczestnictwa $=0 \mathrm{pkt})$.

6) Czy jest lub był(a) Pan/Pani inicjatorem jakiegoś działania na rzecz lokalnej społeczności? $($ Tak $=100$ pkt; Nie $=0$ pkt $)$.

7) Czy korzysta Pan/Pani z następujących źródeł informacji na temat społeczności lokalnej: internetowa strona sołectwa/lista mailingowa sołectwa/Facebook 
- strona mieszkańców Czarnego Lasu/inne źródło? (Korzystanie z 4 źródet $=100$ pkt; korzystanie z 3 źródet $=75$ pkt; korzystanie z 2 źródet $=50$ pkt; korzystanie z 1 źródła $=25 \mathrm{pkt}$; niekorzystanie z żadnego $=0 \mathrm{pkt})^{1}$.

8) Czy głosował(a) Pan/Pani w ostatnich wyborach sołtysa i rady sołeckiej? (Tak $=100 \mathrm{pkt} ;$ Nie $=0 \mathrm{pkt}$ ).

9) Z jakich rodzajów usług oferowanych przez gminę zdarza się korzystać Panu/ Pani i członkom Pana/Pani gospodarstwa domowego - edukacyjnych/rozrywkowych/zdrowotnych/sportowych/innych? (Korzystanie z 5 rodzajów ustug $=100 \mathrm{pkt}$; korzystanie z 4 rodzajów ustug $=80 \mathrm{pkt}$; korzystanie z 3 rodzajów ustug $=60$ pkt; korzystanie z 2 rodzajów ustug $=40$ pkt; korzystanie z 1 rodzaju ustugi $=20$ pkt; niekorzystanie z żadnych ustug $=0$ pkt).

\section{Wyniki}

Średnia wartość wystandaryzowanego wskaźnika wiedzy (w skali od 0 do 100) wyniosła dla ogółu badanych 60,1 pkt. Średnia wartość wskaźnika zaangażowania okazała się wyraźnie niższa - wyniosła 43,8 pkt (Tabela 2.). Obydwa wskaźniki istotnie korelują dodatnio ( $\mathrm{R}$ Pearsona $=0,684$; $\mathrm{p}<0,001)$. Liczebności obu wskaźników różnią się i odbiegają od całkowitej liczebności próby ze względu na występujące braki danych w pojedynczych zmiennych wchodzących w zakres poszczególnych wskaźników.

Tabela 2. Zbiorcze wskaźniki wiedzy o własnej wsi i zaangażowania w sprawy lokalnej społeczności mieszkańców wsi Czarny Las

\begin{tabular}{|l|c|c|c|c|c|}
\hline \multicolumn{1}{|c|}{ Wskaźniki } & N & Minimum & Maksimum & Średnia & $\begin{array}{c}\text { Odchylenie } \\
\text { standardowe }\end{array}$ \\
\hline Wiedzy & 117 & 0,00 & 93,75 & 60,1175 & 17,8980 \\
\hline Zaangażowania & 93 & 6,11 & 95,00 & 43,7814 & 20,3794 \\
\hline
\end{tabular}

Źródło: Opracowanie własne na podstawie wyników zrealizowanego badania.

Średnia wartość analizowanych wskaźników różni się znacząco ze względu na niektóre cechy społeczno-demograficzne mieszkańców, takie jak płeć, wiek, fakt zameldowania w Czarnym Lesie oraz czas zamieszkiwania w tej miejscowości.

Pod względem płci przeciętna wartość zarówno wskaźnika wiedzy, jak i zaangażowania jest wyższa w przypadku kobiet niż mężczyzn (Tabela 3.).

${ }^{1}$ Należy mieć na uwadze, że ten wskaźnik jest wymiarem zaangażowania mieszkańców, ale także pochodną dostępu do internetu i posiadanych kompetencji technologicznych. 
Tabela 3. Wiedza o własnej wsi i zaangażowanie w sprawy lokalnej społeczności w zależności od płci

\begin{tabular}{|c|l|c|c|c|}
\hline \multirow{2}{*}{ Wskaźniki } & \multicolumn{1}{|c|}{ Pleć } & N & Średnia & $\begin{array}{c}\text { Odchylenie } \\
\text { standardowe }\end{array}$ \\
\hline \multirow{2}{*}{ Wiedzy } & kobieta & 67 & 62,4813 & 17,4626 \\
\cline { 2 - 5 } & mężczyzna & 50 & 56,9500 & 18,1585 \\
\hline \multirow{2}{*}{ Zaangażowania } & kobieta & 54 & 46,1008 & 21,1383 \\
\cline { 2 - 5 } & mężczyzna & 39 & 40,5698 & 19,0808 \\
\hline
\end{tabular}

Źródło: Opracowanie własne na podstawie wyników zrealizowanego badania.

Z kolei mając na uwadze wiek respondentów, okazuje się, że oba analizowane wskaźniki przyjmują najwyższe wartości dla najstarszych mieszkańców wsi, a najniższe dla osób najmłodszych (Tabela 4.).

Tabela 4. Wiedza o własnej wsi i zaangażowanie w sprawy lokalnej społeczności w zależności od wieku

\begin{tabular}{|c|c|c|c|c|}
\hline \multirow{4}{*}{ Wskaźniki } & $\begin{array}{c}\text { Przedzial } \\
\text { wiekowy [lat] }\end{array}$ & N & Średnia & $\begin{array}{c}\text { Odchylenie } \\
\text { standardowe }\end{array}$ \\
\hline \multirow{4}{*}{ Wiedzy } & $18-35$ & 23 & 55,0000 & 18,7803 \\
\cline { 2 - 5 } & $36-45$ & 25 & 59,7000 & 14,9360 \\
\cline { 2 - 5 } & $45-65$ & 45 & 61,2500 & 17,7758 \\
\cline { 2 - 5 } & $>65$ & 23 & 62,7717 & 20,2890 \\
\hline \multirow{3}{*}{ Zaangażowania } & $18-35$ & 16 & 40,2431 & 15,0253 \\
\cline { 2 - 5 } & $36-45$ & 19 & 44,7076 & 17,3377 \\
\cline { 2 - 5 } & $45-65$ & 37 & 42,3574 & 20,7252 \\
\cline { 2 - 5 } & $>65$ & 20 & 48,6944 & 26,2895 \\
\hline
\end{tabular}

Źródło: Opracowanie własne na podstawie wyników zrealizowanego badania.

Bez większego wpływu na wartość wskaźników pozostaje poziom wykształcenia respondentów, chociaż osoby o najniższym poziomie edukacji wykazują stosunkowo największą wiedzę o miejscowości. Poziom wykształcenia w zasadzie nie różnicuje skali zaangażowania w funkcjonowanie lokalnej społeczności (Tabela 5.). 
Tabela 5. Wiedza o własnej wsi i zaangażowanie w sprawy lokalnej społeczności w zależności od wykształcenia

\begin{tabular}{|c|l|c|c|c|}
\hline Wskaźniki & \multicolumn{1}{|c|}{ Wyksztalcenie } & N & Średnia & $\begin{array}{c}\text { Odchylenie } \\
\text { standardowe }\end{array}$ \\
\hline \multirow{2}{*}{ Wiedzy } & $\begin{array}{l}\text { podstawowe, gim- } \\
\text { nazjalne } \\
\text { lub zawodowe }\end{array}$ & 8 & 67,1875 & 13,9154 \\
\cline { 2 - 5 } & $\begin{array}{l}\text { średnie lub } \\
\text { pomaturalne }\end{array}$ & 27 & 58,5185 & 21,4864 \\
\cline { 2 - 5 } & wyższe & 82 & 59,9543 & 16,9711 \\
\hline \multirow{2}{*}{ Zaangażowania } & $\begin{array}{l}\text { podstawowe, gim- } \\
\text { nazjalne } \\
\text { lub zawodowe }\end{array}$ & 6 & 45,7407 & 20,0144 \\
\cline { 2 - 5 } & $\begin{array}{l}\text { średnie lub } \\
\text { pomaturalne }\end{array}$ & 22 & 46,1616 & 27,0132 \\
\cline { 2 - 5 } & wyższe & 65 & 42,7949 & 17,9720 \\
\hline
\end{tabular}

Źródło: Opracowanie własne na podstawie wyników zrealizowanego badania.

Nie bez wpływu na wiedzę i zaangażowanie pozostaje długość zamieszkiwania w Czarnym Lesie. Z reguły im dłużej osoba zamieszkuje w miejscowości, tym większe są jej wiedza i zaangażowanie w funkcjonowanie społeczności. Wyjątek stanowią osoby mieszkające w Czarnym Lesie od 11 do 20 lat, które udzielają się w miejscowości nieco aktywniej nawet od mieszkańców, którzy żyją w niej dłużej (Tabela 6.).

Tabela 6. Wiedza o własnej wsi i zaangażowanie w sprawy lokalnej społeczności w zależności od długości zamieszkania w Czarnym Lesie

\begin{tabular}{|c|c|c|c|c|}
\hline \multirow{4}{*}{ Wskaźniki } & $\begin{array}{c}\text { Czas zamieszkania } \\
{[\text { [lat] }}\end{array}$ & $\mathbf{N}$ & Średnia & $\begin{array}{c}\text { Odchylenie } \\
\text { standardowe }\end{array}$ \\
\hline \multirow{4}{*}{ Wiedzy } & $<5$ & 35 & 53,1429 & 16,8971 \\
\cline { 2 - 5 } & $5-10$ & 39 & 61,9872 & 14,1849 \\
\cline { 2 - 5 } & $11-20$ & 26 & 62,1154 & 21,9766 \\
\hline \multirow{3}{*}{ Zaangażowania } & $>20$ & 17 & 67,1324 & 17,5933 \\
\cline { 2 - 5 } & $<5$ & 28 & 35,6349 & 14,9054 \\
\cline { 2 - 5 } & $5-10$ & 27 & 44,8354 & 20,8280 \\
\cline { 2 - 5 } & $11-20$ & 23 & 50,1691 & 23,1985 \\
\hline
\end{tabular}

Źródło: Opracowanie własne na podstawie wyników zrealizowanego badania. 
Istotny jest także fakt zameldowania w Czarnym Lesie. Osoby zameldowane w tej miejscowości posiadają o niej i o okolicy większą wiedzę, częściej też angażują się w życie lokalnej społeczności (Tabela 7.).

Tabela 7. Wiedza o własnej wsi i zaangażowanie w sprawy lokalnej społeczności w zależności od zameldowania

\begin{tabular}{|c|c|c|c|c|}
\hline \multirow{2}{*}{ Wskaźniki } & Zameldowanie & N & Średnia & $\begin{array}{c}\text { Odchylenie } \\
\text { standardowe }\end{array}$ \\
\hline \multirow{2}{*}{ Wiedzy } & tak & 80 & 63,4219 & 16,9474 \\
\cline { 2 - 5 } & nie & 37 & 52,9730 & 18,0334 \\
\hline \multirow{2}{*}{ Zaangażowania } & tak & 64 & 49,0104 & 20,2097 \\
\cline { 2 - 5 } & nie & 29 & 32,2414 & 15,6597 \\
\hline
\end{tabular}

Źródło: Opracowanie własne na podstawie wyników zrealizowanego badania.

Analiza regresji liniowej przy uwzględnieniu wszystkich omówionych czynników wskazuje, że istotną statystycznie zmienną wyjaśniającą - zarówno w zakresie wiedzy, jak i zaangażowania - jest jedynie fakt zameldowania w Czarnym Lesie (odpowiednio $\mathrm{p}=0,02$ i $\mathrm{p}<0,01$ ). Obydwa modele, tj. dla wskaźnika wiedzy i dla wskaźnika zaangażowania, są istotne statystycznie (Tabela 8. i 9.).

Tabela 8. Istotność wpływu wybranych cech populacji mieszkańców na poziom ich wiedzy o własnej miejscowości na podstawie wielozmiennowej regresji liniowej: $\mathrm{F}=3,431 ; \mathrm{p}=0,006$; $\mathrm{R}^{2}=0,135$; skorygowane $\mathrm{R}^{2}=0,135$

\begin{tabular}{|l|c|c|c|c|c|}
\hline \multicolumn{1}{|c|}{ Predyktory } & B & $\begin{array}{c}\text { Bląd } \\
\text { standardowy }\end{array}$ & Beta & t & Istotność \\
\hline Płeć (K/M) & $-5,077$ & 3,227 & $-0,141$ & $-1,573$ & 0,118 \\
\hline Wiek (rosnąco) & 0,793 & 1,272 & 0,060 & 0,623 & 0,534 \\
\hline Wykształcenie (rosnąco) & 1,303 & 1,294 & 0,103 & 1,007 & 0,316 \\
\hline $\begin{array}{l}\text { Czas zamieszkiwania } \\
\text { w Czarnym Lesie (rosnąco) }\end{array}$ & 2,734 & 1,469 & 0,201 & 1,861 & 0,065 \\
\hline $\begin{array}{l}\text { Fakt zameldowania } \\
\text { w Czarnym Lesie (Tak/Nie) }\end{array}$ & 8,691 & 3,668 & 0,225 & 2,369 & 0,020 \\
\hline Stała & 36,677 & 12,084 & & 3,035 & 0,003 \\
\hline
\end{tabular}

Źródło: Opracowanie własne na podstawie wyników zrealizowanego badania. 
Tabela 9. Istotność wpływu wybranych cech populacji mieszkańców na poziom ich zaangażowania w życie lokalnej społeczności na podstawie wielozmiennowej regresji liniowej: $\mathrm{F}=3,431 ; \mathrm{p}=0,006 ; \mathrm{R}^{2}=0,135 ;$ skorygowane $\mathrm{R}^{2}=0,135$

\begin{tabular}{|l|c|c|c|c|c|}
\hline \multicolumn{1}{|c|}{ Predyktory } & B & $\begin{array}{c}\text { Bląd } \\
\text { standardowy }\end{array}$ & Beta & t & Istotność \\
\hline Płeć (K/M) & $-3,974$ & 4,142 & $-0,096$ & $-0,959$ & 0,340 \\
\hline Wiek (rosnąco) & $-0,009$ & 1,645 & $-0,001$ & $-0,006$ & 0,995 \\
\hline Wykształcenie (rosnąco) & 1,445 & 1,618 & 0,099 & 0,893 & 0,374 \\
\hline $\begin{array}{l}\text { Czas zamieszkiwania } \\
\text { w Czarnym Lesie (rosnąco) }\end{array}$ & 2,105 & 1,724 & 0,140 & 1,221 & 0,225 \\
\hline $\begin{array}{l}\text { Fakt zameldowania } \\
\text { w Czarnym Lesie (Tak/Nie) }\end{array}$ & 15,460 & 4,693 & 0,349 & 3,295 & 0,001 \\
\hline Stała & 10,718 & 15,013 & & 0,714 & 0,477 \\
\hline
\end{tabular}

Źródło: Opracowanie własne na podstawie wyników zrealizowanego badania.

\section{Dyskusja i wnioski}

Jak wynika z przeprowadzonych badań, mieszkańcy Czarnego Lasu cechują się dość wysoką wiedzą na temat swojej miejscowości (60,1 pkt na 100 pkt) i jednocześnie istotnie mniejszym zaangażowaniem na rzecz społeczności lokalnej (43,8 pkt na 100 pkt). Wartości te można uznać za stosunkowo wysokie, zwłaszcza biorąc pod uwagę, że ponad $60 \%$ respondentów mieszka tam krócej niż 10 lat, a $85 \%$ krócej niż 20 lat.

Najciekawszym z rezultatów niniejszej pracy jest to, że przy uwzględnieniu wszystkich omówionych czynników istotną statystycznie zmienną wyjaśniającą - zarówno w zakresie wiedzy, jak i zaangażowania - jest przede wszystkim fakt zameldowania. Wynik ten może wskazywać, że bycie zameldowanym w miejscowości (lub nie) może być indykatorem stosunku osoby do miejsca własnego zamieszkania. Osoby zameldowane najprawdopodobniej traktują Czarny Las jako miejsce trwałego osiedlenia. Nie dziwi więc, że angażują się w lokalne wydarzenia i poszerzają swoją wiedzę na temat miejscowości. Z drugiej strony brak zameldowania może być wskaźnikiem traktowania miejsca zamieszkania jako tymczasowego, co skutkuje brakiem zaangażowania i zainteresowania lokalnymi sprawami. Wydaje się, że to ostatnie podejście ma miejsce w Czarnym Lesie na tzw. osiedlu segmentów, gdzie część mieszkań jest wynajmowana i zachodzi duża i szybka rotacja mieszkańców.

Bardziej oczywisty wydaje się pozytywny wpływ długości zamieszkania na poziom wiedzy mieszkańców o ich miejscowości. W przypadku wskaźnika 
zaangażowania jest podobnie, przy czym nieco wyższe wartości niż dla najdłużej zamieszkujących Czarny Las przyjmuje on w grupie osób mieszkających tam od 11 do 20 lat, co może wynikać z faktu, że w pierwszej grupie osób osiedlających się były osoby o wysokim statusie majątkowym, które w niewielkim stopniu uczestniczą w wydarzeniach sołeckich takich jak szkolenia, festyny, ogniska, wyjazdy itd.

Nie dziwi też wysoka istotna korelacja między poziomem wiedzy mieszkańców a stopniem ich zaangażowania w sprawy wsi. Zaangażowanie powoduje przyrost wiedzy, a jednocześnie większa wiedza może skłaniać do zaangażowania. Zachodzić tu może zatem zjawisko sprzężenia zwrotnego dodatniego między tymi czynnikami. Wynik ten należy uznać za cenny również w aspekcie praktycznym. Zachęca on do aktywizowania lokalnych społeczności, gdyż nawet proste działania (takie jak prowadzone w opisywanej miejscowości) mogą przysparzać wiedzy, a ta może stymulować do kolejnych działań, co w efekcie prowadzi do rozwoju społeczności obywatelskich typu smart villages.

Pozostałe uzyskane wyniki, chociaż nie cechują się istotnością statystyczną, też prezentują interesujące tendencje, które można traktować co najmniej jako ciekawe hipotezy badawcze do sprawdzenia w badaniach bardziej precyzyjnych i realizowanych na większej próbie.

I tak np. wynik wskazujący na większą wiedzę i zaangażowanie kobiet może wynikać z faktu zaangażowania młodych mam w opiekę nad dziećmi, która sprzyja nawiązywaniu większej liczby kontaktów, np. podczas spacerów czy korzystania z placu zabaw, a także z większej predyspozycji kobiet niż mężczyzn do nawiązywania i utrzymywania kontaktów.

Ciekawa jest też tendencja wzrostu poziomu wiedzy i stopnia zaangażowania wraz ze wzrostem wieku respondentów. Być może jest to efekt rozwoju alterocentryzmu wraz z dojrzałością życiową oraz dodatkowo zmniejszania liczby obowiązków wynikającego z osiągnięcia stabilizacji życiowej, np. odchowania dzieci czy przejścia na emeryturę.

W przypadku wykształcenia wyższy od przeciętnego poziom wiedzy o wsi u osób o najniższym wykształceniu może wynikać z faktu, że osoby te reprezentują w dużej mierze rdzennych mieszkańców wsi, czyli tych o najdłuższym czasie zamieszkiwania, co - jak zauważono wcześniej - może się przekładać na większą wiedzę. Z kolei niższy poziom zaangażowania w sprawy wsi osób z najwyższym wykształceniem może wynikać z faktu ich czasochłonnej działalności zawodowej, np. sprawowania funkcji kierowniczych lub prowadzenia własnych firm. Dla osób tych Czarny Las nierzadko stanowi jedynie „sypialnię”, gdyż ich aktywność życiowa skoncentrowana jest w dużym stopniu na sprawach zawodowych.

Reasumując, można zauważyć, że obydwa wskaźniki - zarówno wiedzy, jak i zaangażowania - wykazują wewnętrzne zróżnicowanie w odniesieniu do wieku mieszkańców i długości zamieszkiwania we wsi. Mieszkańcy starsi i dłużej zamieszkujący wyróżniają się pozytywnie na tle młodszych i mieszkających w Czarnym Lesie krócej, a zameldowani uzyskują istotnie lepsze wartości wskaź- 
ników niż niezameldowani. Kobiety w obu omawianych wymiarach prezentują się korzystniej na tle mężczyzn. Ponadto największe znaczenie w prognozowaniu zarówno poziomu wiedzy mieszkańców o ich miejscowości, jak i stopnia ich zaangażowania na rzecz własnej społeczności ma fakt zameldowania.

\section{Bibliografia}

Bielska A., Stańczuk-Gałwiaczek M., Sobolewska-Mikulska K., Mroczkowski R. (2021), Implementation of the smart village concept based on selected spatial patterns - A case study of Mazowieckie Voivodeship in Poland, „Land Use Policy”, vol. 104, May, https://doi.org/10.1016/j.landusepol.2021.105366

Błońska E., Murzyn T.J., Obidziński A., Od Czarnolesia do Czarnego Lasu, czyli o powstawaniu tożsamości lokalnej, Urząd Miejski w Grodzisku Mazowieckim, Czarny Las.

Boguszewski R., Herudziński T. (2019), Funkcjonowanie współczesnych społeczności lokalnych na przykładzie wsi Czarny Las. Raport z badań, maszynopis, Pracownia Badań Społecznych Szkoły Głównej Gospodarstwa Wiejskiego, Warszawa.

Hałasiewicz A. (2020), Koncepcje ożywienia $i$ wzmocnienia rozwoju wsi, [w:] J. Wilkin, A. Hałasiewicz (red.), Polska wieś 2020. Raport o stanie wsi, Wydawnictwo Naukowe Scholar, Warszawa.

Herudziński T. (2020), Zmiany na obszarach wiejskich w Polsce-percepcja, wiedza i zaangażowanie ,, starych” $i$,, nowych” mieszkańców wsi, ,Rocznik Lubuski”, t. 46, cz. 2, s. 77-88.

Murzyn T.J. (2020), Zarys dziejów - wieś Czarny Las w latach 1850-1990, [w:] E. Błońska, T.J. Murzyn, A. Obidziński, Od Czarnolesia do Czarnego Lasu, czyli o powstawaniu tożsamości lokalnej, Urząd Miejski w Grodzisku Mazowieckim, Czarny Las.

Skakelja N. (red.) (2018), Innowacje cyfrowe i społeczne w kontekście usług na obszarach wiejskich. Broszura o przykładowych projektach, Europejski Fundusz Rolny na rzecz Rozwoju Obszarów Wiejskich, European Network for Rural Development, Urząd Publikacji Unii Europejskiej, Luksemburg.

Wilkin J. (2020), Zróżnicowana i zmieniająca się polska wieś, [w:] J. Wilkin, A. Hałasiewicz (red.), Polska wieś 2020. Raport o stanie wsi, Wydawnictwo Naukowe Scholar, Warszawa.

\section{KNOWLEDGE OF ONE'S OWN PLACE OF LIVING AND INVOLVEMENT IN LOCAL MATTERS WITH THEIR DETERMINANTS ON THE EXAMPLE OF A RURAL COMMUNITY}

\footnotetext{
Abstract. Changes currently taking place in rural areas in Poland are in line with the concept of "smart villages", which emphasizes the importance of knowledge and innovative activities for the functioning of contemporary rural local communities and the development of rural areas. Referring to the issue of the local community, the article presents the image of the inhabitants of the village of Czarny Las, paying attention to the specificity of this community. In the empirical dimension, the main goal of the authors is to verify the thesis about the dependence between knowledge about one's own town place of living and involvement in local matters on the example of a specific rural community, as well as to determine the factors affecting both dimensions. For this purpose, indicators concerning the individual knowledge and commitment of the inhabitants of the village of Czarny Las in the commune of Grodzisk Mazowiecki, were created and used. Age, sex, education,
} 
time of residence in the examined town and formal registration status were assumed as predictors of both knowledge about one's own village and involvement in its current affairs. In order to determine the statistical significance of the predictors of the inhabitants' knowledge about the village and their involvement in it, the multiple regression analysis was used.

Keywords: knowledge, action, rural areas, local community, smart village. 